\title{
The origin of Vertisols and their relationship to Acid Sulfate Soils in the Senegal valley
}

Laurent Barbiéro a,b,*, Abdallahi Ould Mohamedou c, Lucien Roger d, So^nia Furian e, Alain Aventurier f, Jean Claude Rémy d, Serge Marlet f

a Indo-French Cell for Water Sciences, Department of Civil Engineering, Indian Institute of Science, 560012 Bangalore, India

b IRD-UR 154, Laboratoire des Mécanismes de Transfert en Géologie, 14, Avenue Edouard Belin, 31400 Toulouse, France

c Faculté des Sciences et Techniques, Université de Nouakchott, B.P. 5026, Nouakchott, Mauritania

d INRA-ENSA, Unité de Science du Sol, 2, Place Pierre Viala, 34060 Montpellier Cedex 01, France

e Laboratório de Pedologia, Departamento de Geografia, Universidade de São Paulo, C.P. 8105, Cep 05508-900, Sa o Paulo SP, Brazil

f CIRAD, TA 40/01, 34032 Montpellier Cedex 1, France

Abstract

In the Senegal valley, it is commonly considered that the Acid Sulfate Soils of the delta are fossil soils overlain by more recent sediments, and that the Vertisols, which abruptly overlie a thick sandy horizon, result from a change in the sedimentation mode of the river. However, we show that both soils belong to the same pedological system extending from the delta to the limit of the last marine transgression. This conclusion is based on (1) the study of soil profiles intermediate between Acid Sulfate Soils and Vertisols along a 100-m sequence in the delta, (2) the mineralogy of the clay fraction $(<2 \mathrm{Am})$ in a 200-km transect along the river, and (3) the similarity of the sand size distribution across the textural discontinuity between the horizons. The following processes are involved in the pedological transformations: (1) development of acidity by oxidation of pyrite, (2) neutralization of acidity initially by the carbonate in shell beds, and later by the hydrolysis of easily weatherable silicate clays. The slightly alkaline river water precipitates kaolinite and later smectite at the contact between the strongly acidic and slightly alkaline environments. This results in the formation of a superficial vertic clay horizon surmounting a sandy horizon. Therefore, we emphasize that the soil morphology results from development and control of acidity and not from changes in past climates.

Keywords: Acid Sulfate Soil; Vertisol; Soil genesis; Senegal valley; Senegal delta

\section{Introduction}

During the Quaternary, the sea transgressed several times into the Senegal River valley (Faure et al., 1980). In the middle Holocene, soon after 7000 BP, the Nouakchottian trangression penetrated Pleistocene sand dunes and formed extensive shallow bays and lagoons. Between 4000 and 1800 $\mathrm{BP}$, the shoreline retreated westwards and the Senegal river mouth was forced southwards during the Taffolian regression (Michel, 1973). About 2000 BP, a final transgression formed a large gulf as far inland as Boghé, which is now $380 \mathrm{~km}$ from the coast, and a mangrove vegetation developed in the fluviomarine environment (Lezine, 1997). The sea regressed from Boghé to the present Senegal delta in the medieval period accompanied by the mangrove vegetation, and the remains of this vegetation still occur along creeks in the delta. The sequence of transgression -regression cycles is thought to have had a great influence on soil formation in the Senegal valley. 
Vertisols are common in the Senegal valley and are widely used for irrigated agriculture, particularly rice cultivation. About $75 \%$ of the total cultivated area are Vertisols occurring in depressions (FAO-SEDAGRI, 1973; Favre et al., 1997). In the Vertisols, the superficial clay horizon abruptly overlies a sandy horizon, which is coloured by iron oxides around former roots of mangrove vegetation. The clay and sandy horizons are both $0.5 \mathrm{~m}$ thick in the Senegal delta but together reach $6 \mathrm{~m}$ in the middle valley around Podor. The clay and sandy horizons have been attributed to changes in sedimentation during and after the Nouakchottian transgression. Michel (1973) attributed the sandy horizon to redeposition of Pleistocene (Ogolian) sand dunes during the Nouakchottian transgression, and Deckers et al. (1997) attributed the clay to post-Nouakchottian sedimentation during the Taffolian regression.

Potential acidity accumulated as pyrite in the mangrove roots. The pyrite was later oxidized as the water table level lowered, causing high actual soil acidity. Deckers et al. (1993) suggested that in many instances, the resulting Acid Sulfate Soils (thionic Fluvisols) are buried under more recent sediments of fluviatile origin, and can therefore be considered as fossil soils.

The transgression was also responsible for incorporation of salt into the sediments. A complex redistribution of the salt occurred subsequently in the landscape, involving several processes: (1) concentration by evaporation, (2) aeolian deflation and clay dune formation, (3) transformation of shell banks into gypseous layers, and (4) runoff and deposition of salt in the depressions around the clay dunes (Barbiéro et al., in press).

After the last regression, the soils in the valley developed from the sediments. The most recent soils should occur in the delta, particularly in the present remnants of mangrove areas, whereas the most developed ones should occur upstream, at the limit of the transgression. We have shown that this upstream sequence influences the distribution of salinity and its chemical composition along the valley (Barbiéro et al., in press), and have suggested that the various processes formerly responsible for soil development and features in the middle valley could still be active downriver in the lower middle valley or delta. The aim of this paper is to show that the sequence from the delta to the middle valley is relevant to understanding development of the soil profiles. We focus on the area of transition between the two main soil types (Acid Sulfate Soil and Vertisol), and particularly on the origin of the abrupt textural discontinuity at the base of the Vertisol profile.

\section{Materials and methods 2.1. Site}

Fourteen sites were studied along the Senegal valley, on both the Mauritanian and Senegalese sides of the river, and from the delta to the Podor region (Fig. 1). The semiarid climate is characterized by a wet season (approximately $200 \mathrm{~mm}$ of rainfall) from July to September, a cold and dry season from October to February, and a hot dry season from March to June. The average temperature is 24 $\mathrm{jC}$ in January and $39 \mathrm{jC}$ in May. The dry and warm winds increase evaporation, so that average Class A pan evaporation exceeds average rainfall for each month and by $>2000 \mathrm{~mm}$ annually (Verheye, 1995). In the floodplain, the water table fluctuates from the topsoil to $1 \mathrm{~m}$ depth in the delta, and from 4to 8-m depth in the Podor region (Zanolin et al., 1997; Hammecker and Maeght, 2002).

\subsection{Soils}

Thionic Fluvisols containing pyrite (FeS2) and jarosite [KFe3(SO4)2(OH)6] occur near the remaining mangroves (Le Brusq et al., 1987; Deckers et al., 1997). Beyond these areas, the most representative soil types are Gypsic Fluvisols, Calcic Gypsic Fluvisols and Vertisols (FAO, ISRIC, ISSS, 1998). Upriver in the middle valley, Vertisols predominate in the depressions (locally Gypsic or Calcic), and Fluvisols occur on the river banks.

\subsection{Fieldwork}


The first step of the fieldwork was in the Diawling National Park, which is a narrow triangle of land between the coast and the Senegal River in southern Mauritania. The flooded area of the park consists of the permanently flooded Gambar basin, the dam reserve of the Organisation for the Development of the Senegal Valley, and the periodically flooded Bell Basin, which includes the estuarine area, whose elevation is greater than that of the Gambar. The fieldwork was concentrated in the Bell Basin between the Birette and Ziré dunes (16j20VN, 17j25VW) close to the Khurumbam Creek, which is a tributary of the Bell Creek (Fig. 1). A 100-m soil sequence was studied perpendicular to the Khurumbam creek bed, and intersecting the present edge of the mangrove area. The soil morphology was based on 11 hand boreholes and 3 pits (P1 to P3), excavated at the lateral transitions of the soil. The horizons are described according to the classification for Acid Sulfate Soils of the International Institute for Land Reclamation and Improvement (Dent, 1986).

The second step of the field work was based on 13 sites along the Senegal valley. Since no notable lateral variations were noticed, the soil morphology was described in isolated profiles from boreholes or excavated pits (P4 -P16). Samples were taken from the main horizons and additional samples from $5 \mathrm{~cm}$ above and below the discontinuity between the clay and sandy horizons.

\subsection{Laboratory work}

Soil $\mathrm{pH}$ was measured in the field (pHfield) and in the laboratory after hydrogen peroxide (30\% $\mathrm{H} 2 \mathrm{O} 2$ ) treatment (pHH2O2) in order to oxidize FeS2 (Van Beers, 1962). The soil water content (Wc) was measured by weighing soil samples before and after oven drying at $105 \mathrm{jC}$. Detailed particle size distribution (clay, 2 silt fractions and 17 sand fractions) was determined by sieving and sedimentation on $100 \mathrm{~g}$ samples. Total carbon content in the samples was determined by dry combustion in an elemental analyser (Thermoquest CN 2100). Organic matter was estimated as 1.724 total carbon. The clay $(<2 \mathrm{Am}$ ) fraction of 30 samples was separated by sedimentation after destruction of the organic matter with dilute $\mathrm{H} 2 \mathrm{O} 2$. Its mineralogy was investigated by X-ray diffraction (XRD) using a Rigaku CN4012A2 diffractometer (cobalt anticathode) on orientated specimens studied under 6 different conditions: $\mathrm{K}$ saturation $(\mathrm{K}), \mathrm{Mg}$ saturation $(\mathrm{Mg})$, glycerol

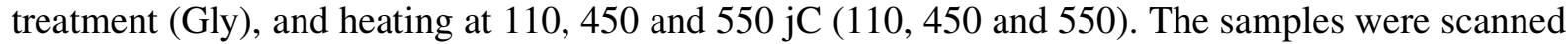
from $0.35 \mathrm{j}$ to $18 \mathrm{j}$ at $0.5 \mathrm{j}$ per minute. $\mathrm{Al}$ and $\mathrm{Fe}$ between the layers were removed from four samples

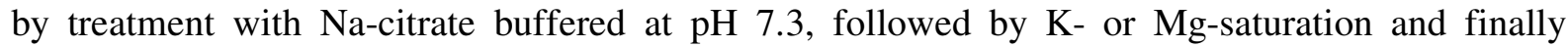
heating at $110 \mathrm{jC}$ overnight (Cit-K-110 or Cit-Mg-110 treatment) (Tamura, 1958; Robert and Tessier, 1974).

Cation exchange capacities (CEC) of the soil samples were measured by the cobalt hexamine trichloride non pH-buffered method (AFNOR NF X31-130, of AFNOR, 1994). The pH of the collected samples was adjusted to within the range over which the cobalt hexamine complex is stable (Ciesielski and Sterckeman, 1997). Cobalt ion concentration was measured by ICP Varian (Vista) in the exchange solution. The CEC of the organic matter was estimated as 250 meq $100 \mathrm{~g}_{-} 1$ organic matter. The remainder of the CEC was attributed to the clay fraction.

For six samples collected along the valley in the clay horizon of profiles P4, P5, P8, P10, P14 and $\mathrm{P} 15$, the $<2$-Am fraction was dissolved with hydrofluoric acid, and the extracted potassium, aluminium and silica were measured by atomic absorption spectroscopy. After digesting the clay from the same samples in $\mathrm{HF}+\mathrm{HClO} 4$ in teflon bombs, iron was determined by flame atomic absorption spectroscopy using the 373.7-nm wavelength (Voinovitch et al., 1962).

The relative abundance of clay mineral groups (kaolinite, smectite and illite) was calculated by three methods:(i) (Method M1). The percentage composition of the clay groups was determined semi-quantitatively from the area under selected XRD peaks, following standard procedures of Biscaye (1965). As the XRD method is semi-quantitative with an accuracy of about $10 \%$ of the 
relative clay mineral abundance, we quote values to the nearest $1 \%$ (Kahle et al., 2002).(ii) (Method M2). The potassium measured after $\mathrm{HF}+\mathrm{HClO} 4$ digestion was attributed entirely to illite. The percentage of illite in the samples was calculated as follows:

illite $_{\text {sample } \%}=100 .\left(\mathrm{K}_{\text {sample } \%} / \mathrm{K}_{\text {illite }}\right)$

where illitesample \% is the percentage of illite in the sample, Ksample\% is the percentage of $\mathrm{K}$ in the solution after $\mathrm{HF}+\mathrm{HClO} 4$ digestion and Killite is the weight percentage of $\mathrm{K}$ in the illite. An illite with iron in the tetrahedral position was considered for this calculation:

illite $=\left[\mathrm{Si}_{6.7}\left(\mathrm{Al}_{0.65}, \mathrm{Fe}^{3+}{ }_{0.65}\right)\right] \mathrm{O}_{20}\left[\left(\mathrm{Al}_{1.95}, \mathrm{Fe}^{3+}{ }_{1.95}\right)\left(\mathrm{Fe}^{2+}{ }_{0.05}, \mathrm{Mg}_{0.05}\right)\right](\mathrm{OH})_{4} \mathrm{~K}_{1.4}$

which gives Killite $=6.4 \%$. The contribution of illite to the CEC of the clay fraction was calculated assuming that illite has an exchange capacity of $25 \mathrm{meq} 100 \mathrm{~g} \_$. The relative proportions of kaolinite and smectite were calculated from the CEC of the clay fraction based on their assumed exchange capacities (kaolinite: 10 meq 100_ 1; smectite: 100 meq 100 g_ 1).(iii) (Method M3). The potassium measured after $\mathrm{HF}+\mathrm{HClO} 4$ digestion was attributed to illite. The proportion of $\mathrm{Fe}(\mathrm{Fea})$ attributed to illite was calculated as follows:

$\mathrm{Fe}_{\mathrm{a}}=\left(\mathrm{Fe}_{\text {illite }}\right.$. illite $\left._{\text {sample } \%}\right) / 100$

where Feillite is the weight percentage of $\mathrm{Fe}$ in the illite calculated from the structural formula in Eq. (2) $($ Feillite $=2 \%)$.

In a recent study of clay minerals in the Podor region, Favre et al. (2002) calculated that structural Fe (tetrahedral and octahedral) content is about $120 \mathrm{cmol} \mathrm{kg} \_1$ in the smectite. Therefore, after subtracting this value (Fea), the remaining $\mathrm{Fe}(\mathrm{Feb})$ was attributed entirely to a smectite of ironbeidellite type:

$$
\text { beidellite }=\left[\mathrm{Si}_{7}\left(\mathrm{Al}_{0.5}, \mathrm{Fe}^{3+}{ }_{0.5}\right)\right] \mathrm{O}_{20}\left[\left(\mathrm{Al}_{2.2}, \mathrm{Fe}^{3+}{ }_{2}\right)(\mathrm{OH})_{4} \mathrm{Ca}_{0.1} \mathrm{Na}_{0.2}\right.
$$

The percentage of beidellite was calculated as follows:

$$
\text { beidellite }_{\text {sample } \%}=100\left(\mathrm{Fe}_{\mathrm{b}} / \mathrm{Fe}_{\text {beidellite }}\right)
$$

where Febeidellite is calculated from the structural formula of the beidellite in Eq. (4) (17.3\%). The proportions of $\mathrm{Al}$ attributed to illite (Ala) and beidellite following:

$$
\begin{aligned}
& \mathrm{Al}_{\mathrm{a}}=\left(\mathrm{Al}_{\text {illite }} \cdot \text { illite }_{\text {sample } \%}\right) / 100 \\
& \mathrm{Al}_{\mathrm{b}}=\left(\mathrm{Al}_{\text {beidellite }} \cdot \text { beidellite }_{\text {sample } \%}\right) / 100
\end{aligned}
$$

where Alillite and Albeidellite are the respective weight percentage of $\mathrm{Al}$ in the illite and beidellite (1\% and 9\%). After removing Ala and Alb, the remaining $\mathrm{Al}$ (Alc) was attributed to kaolinite with no substitution of $\mathrm{Fe}$ for $\mathrm{Al}$ :

$$
\text { kaolinite }=\mathrm{Si}_{4} \mathrm{O}_{10} \mathrm{Al}_{4}(\mathrm{OH})_{8}
$$

The percentage of kaolinite in the samples was calculated as follows:

$$
\text { kaolinite }_{\text {sample } \%}=100\left(\mathrm{Al}_{\mathrm{c}} / \mathrm{Al}_{\text {kaolinite }}\right)
$$

where Alkaolinite is the weight percentage of $\mathrm{Al}$ in the kaolinite calculated from the structural 
formula of kaolinite $(21 \%)$.

Finally, the remaining silica was attributed to quartz, which was detected in small quantities in the < 2-Am fraction by XRD.

3. Results

\subsection{Soil morphology}

Fig. 2 shows the soil distribution pattern in the delta. In the creek bed at the extreme west of the transect, unripe silty clay rich in pyrite occurs at 0.4-m depth (Gr horizon, pHfield $=5.6$, $\mathrm{pHH} 2 \mathrm{O} 2=2.7, \mathrm{Wc}=60 \%$, and is overlain by a greyish brown, half ripe and strongly acidic silty clay with yellow mottles of jarosite $(\mathrm{Gj}$ and Bj horizons, $\mathrm{pHfield}=4.5, \mathrm{pHH} 2 \mathrm{O} 2=2.6, \mathrm{Wc}=42 \%)$. The superficial greyish brown horizon has a coarse prismatic structure mottled with reddish brown iron oxide at the base $(\mathrm{Bg}$ horizon, $\mathrm{pHfield}=4.7, \quad \mathrm{pHH} 2 \mathrm{O} 2=4.3)$. The surface soil has a soft powdery structure.

Near $12 \mathrm{~m}$ to the east, a bleached sandy horizon occurs at $0.2-\mathrm{m}$ depth and is discontinuous between 12 and $24 \mathrm{~m}$ (Fig. 3). Its lower boundary is abrupt, wavy and emphasized by reddish hematite mottles, whereas its upper boundary is gradual and irregular. The thickness of this horizon increases progressively from 0.2 to $0.95 \mathrm{~m}$ between 24 and $100 \mathrm{~m}$. It is locally bleached, but around the former mangrove roots, it is coloured by iron oxide (Fig. 4). Various undulating clay laminae 1 - 5 $\mathrm{cm}$ thick occur in the sandy horizon, and are sometimes anastomosing. In the unripe mud located deep below, the pHfield reaches 3.9 (pHH O2 = 2.9) and $\mathrm{Wc}$ is about 33\%. Near $66 \mathrm{~m}$ east of the creek bed, the surface structure changes abruptly from soft powder to centimetric platelets, where there is an abrupt increase in topsoil clay content from 19 to $29 \%$. The thickness of this clay topsoil horizon increases irregularly from $66 \mathrm{~m}$ to the end $(100 \mathrm{~m})$ of the surveyed transect (Fig. 5), where a decimetric vertic structure appears and the clay content reaches $55 \%$ (pHfield $=6.1$, pHH O2 $=5.9$ and $\mathrm{Wc}=17 \%$ ). The lower boundary of the vertic clay horizon is abrupt and many of the laminae located in the sandy horizon merge into its base.

Two layers rich in shells and shell fragments occur in the western part of the sequence. The first layer at 0.6-m depth is composed of Anadara senilis fragments and the second (0.9-m depth) of Thympanotonus fuscatus shells. In both layers, the shells are strong only to distances of 33 and 62 $\mathrm{m}$, respectively. Further east, they are replaced by shells weathered by dissolution, and yet further east centimetric gypseous nodules replace the two shell layers.

Up the Senegal valley, the Profiles P4 to P16 have the same horizon sequence as that described in the final part of the sequence (Profile P3, Fig. 5). Three main horizons are distinguished from top to bottom: a brown -grey clay with decimetric vertic structure (pHfield ranging from 5.9 to 6.7 along the valley), underlain by a sandy horizon with an abrupt, slightly undulating boundary. The sandy horizon is usually bleached but sometimes coloured by iron oxides, and contains several undulating clay laminae. Finally, an irregular merging boundary leads to a black mud. Profiles P3 -P16 differ only in the thickness of the horizons (Fig. 6).

\subsection{Sand fraction granulometry}

In the delta (P1 to P3), there is a bimodal distribution of the sand fraction, with modes at 0.13 and $1.25 \mathrm{~mm}$ in all the horizons (Fig. 7). Along the valley (P4 to P16), the grainsize distribution varies significantly between profiles. A coarse unimodal distribution occurs in P6 and P7, a fine unimodal distribution in $\mathrm{P} 4$ and P14, a bimodal distribution in P15, etc. (Fig. 8). However, the sand grain-size distribution is always similar on either side of the abrupt discontinuity between the vertic clay horizon and the sandy horizon.

\subsection{Clay mineralogy}


X-ray diffraction of the $<2$-Am fractions indicated the presence of kaolinite, illite, smectite, interstratified illite - smectite and quartz. Kaolinite, illite and smectite are dominant, whereas quartz and interstratified minerals are present in only small quantities, as reported by Haefele et al. (2002) at Ndiaye in the delta. Examples of typical XRD diffractograms are given in Figs. 9 and 10.

Kaolinite gives a sharp main peak ranging from 7.12 to $7.19 \mathrm{~A}^{\circ}$ in all the samples. However, in the samples from the unripe mud, the peak disappears after heating at $550 \mathrm{jC}$, whereas in the clay laminae and the vertic clay horizons throughout the valley, the kaolinite peak decreases after heating to $550 \mathrm{jC}$ but does not disappear completely. Smectite occurs in the unripe mud, the vertic clay horizon and the clay laminae in Profiles P3 to P16, whereas in Profiles P1 and P2, it is present only in the unripe mud. The main peak is located around $15-17 \mathrm{~A}^{\mathrm{o}}$ (Fig. 9), shifts to $19 \mathrm{~A}^{\mathrm{o}}$ after Mg-Gly treatment, and decreases to $10 \mathrm{~A}^{\circ}$ after heating at $400 \mathrm{jC}$. After this treatment, some peaks with interlayer distances $>10 \mathrm{~A}^{\mathrm{o}}$ persisted, though heating at $550 \mathrm{jC}$ removed them. After sodium citrate treatment with K-saturation and heating at $110 \mathrm{jC}$ (Cit-K110), a 12.5- $\mathrm{A}^{\circ}$ peak appeared. Using the same treatment but with $\mathrm{Mg}$-saturation (CitMg-110), the $12.5 \mathrm{~A}^{\mathrm{o}}$ peak was absent or less pronounced. In most of the samples, after Cit-K-110 processing, the amplitude of the $10-\mathrm{A}^{\circ}$ peak increases compared to Cit-Mg110 processing.

In contrast, smectite is hardly detectable in the clay lamina of Profile P2, where it forms a plateau between 14 and $24 \mathrm{~A}^{\circ}$. In these samples, some peaks correspond to an interlayer spacing $>22 \mathrm{~A}^{\circ}$. A regular change in the smectite occurs along the 100-m sequence in the delta from the clay lamina in $\mathrm{P} 2$, where smectite is hardly identified, to the vertic clay in P3, where the peak is clearly defined (Fig. 10).

A mica, whose main peak is located between 9.83 and $10.1 \mathrm{~A}^{\circ}$, occurs in the unripe mud and the clay horizon from Profiles P2 to P13. Interstratified minerals exhibiting a main peak $>20 \mathrm{~A}^{\circ}$ occur in Profiles P4 to P8. Lastly, a slightly weathered illite with interlayer distance ranging from 10.5 to $12 \mathrm{~A}^{\mathrm{o}}$ may occur in Profiles P8 to P13, and also in two samples of the unripe mud in P1 and P2.

\subsection{Semi-quantitative composition of the clay fractions}

Table 1 shows the relative proportions of kaolinite, smectite and illite groups in the samples from the vertic horizon in Profiles P4 -P16. The mineral ratios calculated from methods M1, M2 and M3 are presented in Fig. 11. Upriver, the ratio smectite/kaolinite slowly increases, illite/kaolinite decreases and smectite/illite increases.

\section{Discussion}

\subsection{Soil morphology}

The soil observed on the western part of the transect (Fig. 2) has the typical morphology of an Acid Sulfate Soil. Gr, Gj, Bj, Bg and A horizons (criteria used in the ILRI classification; Dent, 1986) occur from the bottom to the top of the profile. The horizon sequence is determined by two main pedological processes: ripening of the mud involving principally an irreversible loss of water, and the oxidation of iron minerals. The pyrite in the Gr horizon was produced by the activity of the sulfate-reducing bacteria in waterlogged sediments rich in organic matter. The pale yellow colour in the $\mathrm{Gj}$ and $\mathrm{Bj}$ horizons results from jarosite, which is generally observed when $\mathrm{pH}$ is $<3.7$ and $\mathrm{Eh}$ $>400 \mathrm{mV}$ (Dent, 1986). At higher $\mathrm{pH}$ values, jarosite is metastable with respect to goethite and ultimately, it is hydrolysed to iron oxide, predominantly geothite and sometimes hematite (Van Breemen, 1976), as observed at the top of the Bj horizon.

At the top of the profile and towards the eastern end of the sequence, there is evidence of chemical reactions induced by the acidity, following oxidation of pyrite, and also evidence of acid neutralization by the soil alkalinity. The alkalinity is mainly provided by carbonates, exchangeable bases and easily weatherable silicates. The first control of acidity is the progressive dissolution of the shells, leading to disappearance of the calcareous layers. The calcium released in the saline and sulfate-rich environment precipitates as centimetric gypsum nodules, indicating the former presence 
of the shell beds in the soil (Dent, 1980, 1986). According to Van Breemen (1973a,b, 1976), acid neutralization by protonation of clay minerals occurs after dissolution of the carbonates. The resulting protonated clays are not stable (Laudelou and Eeckman, 1958) and their crystalline structure is attacked by $\mathrm{H}+$, liberating silica and metal ions, principally aluminium, iron, magnesium and potassium into the soil solution (Fitzpatrick et al., 1998). Van Breemen (1973a,b, 1976) showed that there is significant dissolution of silicate clays at $\mathrm{pH}<4$. The acid hydrolysis of aluminosilicate clays can contribute $10 \%$ of the buffering of the acid produced by oxidation of pyrite (Dent and Raiswell, 1982).

We therefore interpret the sandy bleached horizon as resulting from acid hydrolysis of aluminosilicate clays, leading to relative accumulation of quartz, and not as a result of sedimentation. This is based on the following observations: 1 . The sandy material appears first at about $20-\mathrm{m}$ depth, where presently the oxidation of pyrite and jarosite creates the most acid field conditions. 2. In the unripe mud, the horizontal shell beds indicate stratification, which is intersected by the lower boundary of the sandy horizon. 3. The bimodal sand size distribution (Fig. 6) persists throughout the sequence in spite of the textural differences in the three horizons, namely, mud, sand and clay. This would not happen if the soil profile were a result of different sedimentation episodes, as the different sedimentation regimes required for the deposition of these three materials would not preserve the same sand size distributions.

The textural discontinuity between the mud and the sandy material is therefore interpreted as a pedological transformation front, resulting from acidification, dissolution of aluminosilicate clays and relative accumulation of quartz skeleton. The origin of the textural discontinuity between the sandy horizon and the clay vertic horizon will be discussed below using other data collected along the valley.

\subsection{Clay fraction of the unripe mud}

In the unripe mud (Profiles P1 and P2), the $<2$-Am fraction is composed of kaolinite, smectite and micas. The presence of a peak at about $12.5 \mathrm{~A}^{\circ}$ after Cit-K-110 processing

may indicate neoformed smectite (Robert, 1975). In the same samples, the increase of the peak at $10 \mathrm{~A}^{\mathrm{o}}$, indicating collapse of the smectite layer after $\mathrm{K}$ saturation, should characterize a smectite formed from mica. However, the presence of well-crystallized mica and the absence of interstratified minerals in spite of some slightly weathered illite suggest that the transformation of the mica into smectite did not occur in the mud. The mineralogy of the clay fraction in the mud of Profiles P1 and P2 therefore seems to be that of the original river sediment, which is in agreement with the composition of sediment at the river mouth (Gac and Kane, 1986). To summarize, the mineralogical profile of the $<2$-Am fraction in the unripe mud is kaolinite, illite and two types of smectite, one of which is formed by transformation of micas and the other by chemical precipitation.

\subsection{Clay fraction of the clay laminae and vertic horizon}

The kaolinite in the samples taken from the clay laminae is slightly heat-resistant and therefore differs from that of the mud. This suggests that it was precipitated in the laminae. In acid sulfate waters, high $\mathrm{Al}$ contents occur as a result of aluminosilicate dissolution, but the geochemistry of $\mathrm{Al}$ is significantly modified by sulfate, so that gibbsite and kaolinite are not the most stable phases (Bigham and Nordstrom, 2000). In some parts of the Senegal delta where the acid soil solution concentrates, Le Brusq et al. (1987) observed soluble aluminium sulfate minerals. However, during overflow of the Senegal River, a neutral or slightly alkaline water with lower ionic concentrations easily infiltrates the sandy horizon of the acid soil. After dilution and partial control of the acidity by the Senegal freshwater, kaolinite can form. The clay laminae undulate in the soil profiles and are linked to the vertic superficial horizon, and may have originated at the moisture front. The geochemical contrast at the contact between the acid water table and the Senegal water should cause precipitation of aluminosilicate, which first forms a gel, as observed in a similar geochemical environment in Spain (Gimeno et al., 1994), and is then quickly reorganized into kaolinite. 
The smectite in the superficial vertic horizon at P3 is better organized than that in the deeper clay lamina in Profile P2 (Fig. 10). The large plateau on the X-ray trace (P2 lamina 1) corresponds to an interlayer spacing $>22 \mathrm{~A}^{\circ}$ and therefore suggests weakly organized smectite layers. It cannot be attributed to interstratified minerals because peaks at 14 and $24 \mathrm{~A}^{\circ}$ are not present simultaneously. Hence, we conclude that smectite was formed later than kaolinite in the clay laminae and vertic horizon, probably when acid conditions were sufficiently buffered in the soil solution.

The mineralogy of the $<2$-Am fraction in the mud differs from that in the clay laminae. Therefore, contrary to our previous claims (Barbiéro et al., 1998), the clay laminae are not the remains of the mud, nor are they formed by redistribution of the clay fraction in the soil profile. They can only be formed by dissolution of the clay fraction of the mud and precipitation in the clay laminae.

\subsection{Changes along the Senegal valley}

The sand size distribution is similar on both sides of the textural discontinuity between the sandy horizon and vertic clay horizon, but varies along the river from one profile to another, suggesting that the discontinuity is pedogenic in origin. Indeed, it is unlikely that the sandy and clay horizons arise from different sedimentation processes, because the clay would not retain exactly the same sand size distribution as the sand below. At the contact between the sandy horizon and the vertic clay horizon, the strong acidity is buffered and there is no evidence of clay dissolution. Therefore, we interpret the contact as a pedological transformation front, where clay is precipitated, so that the clay horizon is expanding at the expense of the sandy material.

In the vertic clay horizon of Profiles P3 -P16, the kaolinite remains similarly heatresistant to that observed in the clay laminae, and was probably precipitated in the same conditions, i.e. in a very contrasting chemical environment and in the initial stage of acid buffering.

The smectite is better crystallized in the vertic clay horizon than in the clay lamina of P2. The peak at $12.5 \mathrm{~A}^{\mathrm{o}}$ observed after the Cit-K-110 treatment disappears after the Cit-Mg 110 treatment, indicating formation by chemical precipitation, which probably occurred after the buffering of acidity. The increase in smectite contents upstream indicates an increasing period of precipitation of smectite.

The crystallinity of the illite is good in the downstream Profiles P4, P5 and P6, but upriver the intensity of the peak decreases, the width increases and the peak almost disappears at P12, which agrees with the relative proportions calculated from $\mathrm{CEC}$ and chemical data after $\mathrm{HF}+\mathrm{HClO} 4$ digestion. The parallel increases in smectite contents and the $10-\mathrm{A}^{\circ}$ peak after the Cit-K-110 treatment indicate the transformation of illite into smectite. Our results agree with the observation of Haefele et al. (2002), who also observed the presence of kaolinite and smectite without illite in the clay fraction at Fanaye close to P12.

To summarize, taking the kaolinite content as a reference in the clay fraction, the ratio smectite/kaolinite increases upriver because of chemical precipitation of smectite and also because of the progressive transformation of illite into smectite. The maximum proportion of smectite in the clay fraction in our samples was $46 \%$, but upriver beyond our sequence up to $70 \%$ of smectite and $30 \%$ of kaolinite were reported in more superficial samples of the vertic horizon (Favre et al., 2002).

\section{Conclusions}

In a previous study, we showed that eolian deposition is a major soil forming factor in the Senegal valley (Mohamedou et al., 1999; Barbiéro et al., in press). The present paper suggests that the development and buffering of soil acidity is also a major factor in the formation of the soil profiles. Acid Sulfate Soils (thionic Fluvisols) occur in the delta under the remains of mangrove vegetation, and their mineralogical composition suggests they are inherited from sediments of the Senegal River.

The oxidation of pyrite causes strong acidity in the soil. This is buffered first by dissolution of the shell deposits, which results in the formation of gypseous layers. Subsequently, it is buffered by protonation and acid hydrolysis of aluminosilicate clays, which result in the formation of a sandy 
horizon by residual accumulation of the quartz skeleton. Two main pedological fronts occur between the Acid Sulfate Soils and Vertisols. The first pedological front is the undulating textural discontinuity between the deep mud with high pyrite content and the overlying sandy horizon. During the rainy season, the Senegal river overflows and neutral or slightly alkaline freshwater infiltrates into the soil profile. At the contact between the fresh Senegal water and the acidic water rich in $\mathrm{Al}, \mathrm{Fe}$ and $\mathrm{Si}$, kaolinite precipitates forming clay laminae in the sandy horizon. Subsequently, smectite precipitates when the acid conditions are sufficiently buffered. Clay precipitation results in the formation of a superficial clay horizon, which acquires a vertic structure, and produces the second pedological front between the sandy horizon and the vertic clay horizon. The similar morphology of the Vertisols in the eastern part of the sequence described in the delta and those observed along the valley suggests that they belong to the same soil system. Upriver a thickening of the soil cover and progressive mineralogical changes occur in the vertic horizon. The proportion of smectite in the clay fraction increases by smectite neoformation and transformation of illite into smectite.

The pedological processes indicated by this study disagree with the previous interpretation of the formation of soil profiles in the valley. We conclude that Acid Sulfate Soils in the delta are not fossil soils buried under more recent deposits (Deckers et al., 1993), but are undergoing transformations related to the development and buffering of acid conditions. Also, we do not interpret the current Vertisols as resulting from three successive deposits, pre-Nouakchottian acid sulfate mud, Nouakchottian sand and post-Nouakchottian clay deposits (Michel, 1973). Instead we suggest that they have formed from clay precipitation in the sand after buffering of the acid conditions. The standard succession of the Vertisol profile over a sandy horizon over unripe mud is the result of pedological processes. This succession is thin in the delta but reaches a thickness of about $6-7 \mathrm{~m}$ in the Podor region $200 \mathrm{~km}$ inland. Therefore, it is not necessary to resort to drastic changes in environmental conditions to explain the discontinuities observed in the soil profiles along the valley. Indeed there is no independent evidence of changes in palaeoenvironmental conditions. The soils of the Senegal valley can be considered as a chronosequence, the most recent soils being observed downriver in the delta, and the most developed ones upriver at the border of the last transgression. This chronosequence may prove to be useful in various studies, particularly in understanding the buffering of alkalinity brought during each irrigation. The Senegal water used for irrigation is suspected to cause eventual soil degradation by alkalization (Boivin, 1997). In order to calculate the alkalinity balance, the current clay precipitation identified in this study should be taken into account. Irrigated soils of the Podor region should eventually develop similar chemical features to those located upstream between Podor and Boghé, which have been naturally flooded by water of the same quality for a longer time.

Acknowledgements

This work was partially supported by a research grant from AUPELF-UREF (Agence Francophone pour l'Enseignement Supérieur et la Recherche), awarded to Abdallahi Ould Mohamedou. We also thank Vasanthi Dass for the editorial advice.

\section{References}

AFNOR, 1994. Qualité des sols : recueil des normes françaises 1994. AFNOR, Paris-La Défense.

Barbiéro, L., Ould Mohamedou, A., Caruba, R., 1998. Influence de la maturation des sols de mangrove sur la déflationéolienne et la formation de dunes argileuses dans le delta du fleuve Sénégal. Comptes Rendus de l'Académie des Sciences Paris 327, 115-120.

Barbiéro, L., Ould Mohamedou, A., Laperrousaz, C., Furian, S., Cunnac, S., in press. Polyphasic origin of salinity in the Senegal delta and middle valley. Catena, submitted.

Bigham, J.M., Nordstrom D.K., 2000. Iron and aluminium hydroxysulfate minerals. In: Alpers C.N., Jambor J.L., Nordstrom D.K. (Eds), Sulfate minerals. Crystallography, geochemistry, and environmental significance. Reviews in Mineralogy and Geochemistry 40, 351-403. 
Biscaye, P.E., 1965. Mineralogy and sedimentation of a recent deep-sea clay in the Atlantic Ocean, adjacent seas and oceans. Geological Society of America Bulletin 76, 803-832.

Boivin, P., 1997. Soil degradation in irrigation schemes in the Senegal river middle valley: mechanisms, characterization methods and actual situation. In: Miézan, K.M., Wopereis, M.C.S., Dingkuhn, M., Deckers, J., Randolph, T.F., (Eds), Irrigated rice in the Sahel : Prospects for sustainable development. Warda/Adrao, Dakar, Senegal, pp. 37-49.

Ciesielski, H., Sterckeman, T., 1997. A comparison between three methods for the determination of cation exchange capacity and exchangeable cations in soils. Agronomie 17, 9-16.

Deckers, J., Raes, D., Merckx, R., Diallo, A., 1993. The fate of Salic and Thionic Fluvisols under irrigated rice in the Senegal river delta. Pedologie 43, 389-401.

Deckers, J., Dondeyne, S., Vandekerckhoven, L., Raes, D., 1997. Major soils and their formation in the West African Sahel. In: Miézan, K.M., Wopereis, M.C.S., Dingkuhn, M., Deckers, J., Randolph, T.F., (Eds), Irrigated rice in the Sahel : Prospects for sustainable development. Warda/Adrao, Dakar, Senegal, pp. 23-35.

Dent, D., 1980. Acid sulphate soils : morphology and prediction. Journal of Soil Science 31, 81-99.

Dent, D., 1986. Acid sulphate soils : a baseline for research and development. ILRI Publication 39. Wageningen, The Netherlands.

Dent, D.L., Raiswell, R.W., 1982. Quantitative model to predict the rate and severity of acid sulfate development : a case study, the Gambia. In: Dost H., Van Breemen N., (Eds), Proceedings of the Bangkok symposium on Acid Sulfate Soils. ILRI Publication 31. Wageningen, The Netherlands, pp. 73-95.

FAO-SEDAGRI, 1973. Etude hydro-agricole du bassin du fleuve Sénégal. Etude pédologique, 251 p. map $1 / 50,000^{\mathrm{e}}$.

FAO, ISRIC, ISSS, 1998. World Reference Base for Soil Resources, Rome, Italy.

Faure, H., Fontes, J.C., Hebrard, L., Monteillet, J., Pirazzoli, P.A., 1980. Geoidal changes and shore-level tilts along Holocene estuaries: Sénégal river area, West Africa. Science 210, 421423.

Favre, F., Boivin, P., Wopereis, M., 1997. Water movement and soil swelling in a dry, cracked Vertisol. Geoderma 78, 113-123.

Favre, F., Tessier, D., Abdelmoula, M., Génin, J.M., Gates, W.P., Boivin, P., 2002. Iron reduction and changes in cation exchange capacity in intermittently waterlogged soil. European Journal of Soil Science 53, 175-193.

Fitzpatrick, R.W., Merry, R.H., Williams, J., White, I., Bowman, G., Taylor, G., 1998. Acid Sulfate Soil Assessment: Coastal, Inland and Mine spoil conditions. National Land and Water Resources Audit Methods Paper. Canberra, Australia.

Gac, J.Y., Kane, A., 1986. Le fleuve Sénégal: I. Bilan hydrologique et flux continentaux de matières particulaires à l'embouchure. Sciences Géologiques Bulletin 39, 99-130.

Gimeno, M.J., Tena, J.M., Auque, L.F., Mandado, J., 1994. Geochemical characterization of the acidic waters in the Arroyo del Val system Zaragoza, Spain. Boletin Real Sociedad Espanola de Historia Natural: Seccion Geologica 89, 5-17.

Haefele, S.M., Wopereis, M.C.S., Wiechmann, H., 2002. Long-term fertility experiments for irrigated rice in the West African Sahel: agronomic results. Field Crops Research 78, 119-131.

Hammecker, C., Maeght, J.L., 2002. Suivi etévaluation de la qualité des eaux et de l'impact environnemental des aménagements du secteur N'Gallenka. 2nd report, Institut de Recherche pour le Développement, Dakar, Senegal.

Kahle, M., Kleber, M., Jahn, R., 2002. Review of XRD-based quantitative analyses of clay minerals in soil: the suitability of mineral intensity factors. Geoderma 109, 191-205.

Laudelou, H., Eeckman, J.P., 1958. La stabilité chimique des suspensions d'argile saturées par l'ion hydrogène. International Society of Soil Science Transactions II, IV Commission, Hamburg 2, 193-199.

Le Brusq, J.Y., Loyer, J.Y., Mougenot, B., Carn, M., 1987. Nouvelles paragenèses à sulfates d'aluminium, de fer, et de magnésium, et leur distribution dans les sols sulfatés acides du 
Sénégal. Science du Sol 25, 173-184.

Lezine, A.M., 1997. Evolution of the West African mangrove during the Late Quaternary: A review. Geographie Physique et Quaternaire 51, 405-414.

Michel, P., 1973. Les bassins des fleuves Sénégal et Gambie. Etude géomorphologique. Mémoire ORSTOM 63. Paris, France.

Mohamedou, A.O., Aventurier, A., Barbiéro, L., Caruba, R., Valles, V., 1999. Geochemistry of clay dunes and associated pan in the Senegal delta (Mauritania). Arid Soil Research and Rehabilitation 13, 265-280.

Robert, M., 1975. Principes de détermination qualitative des minéraux argileux à l'aide des Rayons X. Annales Agronomiques 26, 363-399.

Robert, M., Tessier, D., 1974. Méthode de préparation des argiles des sols pour desétudes minéralogiques. Annales Agronomiques 25, 859-882.

Tamura, T., 1958. Identification of clay minerals from acid soils. Journal of Soil Science 9, 141147.

Van Beers, W.F.J., 1962. Acid Sulphate Soils. ILRI Bulletin 3, Wageningen, The Netherlands.

Van Breemen, N., 1973a. Dissolved aluminium in Acid Sulfate Soils and in acid mine waters. Soil Science Society of America Proceedings 37, 694-697.

Van Breemen, N., 1973b. Soil forming processes in acid sulfate soils. In Dost H. (Ed.), Acide Sulfate Soil. Proceedings of the First International Symposium. Vol. 1, Wageningen, The Netherlands.

Van Breemen, N., 1976. Genesis and solution chemistry of acid sulfate soils in Thailand. Agricultural Research Report 848, Pudoc, Wageningen, The Netherlands.

Verheye, W.H., 1995. Impact of climate and soil conditions on conception and implementation of irrigation schemes in the Senegal River basin. Agricultural Water Management 28, 73-94.

Voinovitch, I.A., Debras-Guedon, J., Louvrier, J., 1962. L'analyse des silicates. Hermann, Paris.

Zanolin, A., Tchani, J., Barbiéro, L., Boivin, P., Descloitres, M., 1997. Apport de la méthodeélectrique pour la reconnaissance hydrogéologique et l'étude des variations superficielles en zone sédimentaire subsaharienne. In: BRGM, INRA, ORSTOM and UPMC (Eds), Géophysique des sols et des formations superficielles, Bondy, France, 173-178.

Figure captions

Fig. 1: Locations of the studied sites: + are points sampled along the Senegal valley (P4 to P16), and of the soil sequence studied in the Diawling National Park, Senegal delta (P1-3).

Fig. 2: Soil morphology along the sequence in the delta.

Fig. 3: Profile of Acid Sulfate Soil (P1), with the appearance of the sandy horizon at about $20 \mathrm{~cm}$ depth. Jarosite appears as yellow mottles and oxidizes to goethite/hematite at the base of the sandy horizon.

Fig.4: Profile of Acid Sulfate soil (P2). The sandy horizon is well developed with clay laminae. Clay content increases abruptly from 19 to $29 \%$ in the topsoil on the right side of the photo.

Fig. 5: Profile of Vertisol (P3). From top to bottom: topsoil vertic clay horizon, sandy horizon with clay laminae, and unripe mud at $90 \mathrm{~cm}$ depth.

Fig. 6: Distribution of the main horizons from the delta to the middle valley.

Fig. 7: Distribution of sand size fractions along the soil sequence in the delta.

Fig. 8: Distribution of sand size fractions on either side of the textural discontinuity between vertic clay horizon (Clay) and bleached sandy horizon (Sand) along the Senegal valley.

Fig. 9: Examples of X-ray diffraction traces of the clay fraction from the vertic horizon of P3.

Fig. 10: X-ray diffraction traces showing the gradual evolution of smectite from clay lamina at P2 and $\mathrm{P} 3$ to vertic clay horizon at $\mathrm{P} 3$.

Fig. 11: Ratios of smectite/illite, illite/kaolinite and smectite/kaolinite along the Senegal valley, using methods M1, M2 and M3 (see text). Straight lines denote linear trends of the ratios. 
Table 1: Relative proportions of kaolinite, smectite and illite in the clay fraction of the vertic horizon along the Senegal valley. Calculations based on relative XRD peak intensity (Method M1), $\mathrm{K}$ and CEC (Method M2), K, Fe and Al (Method M3, see text). 


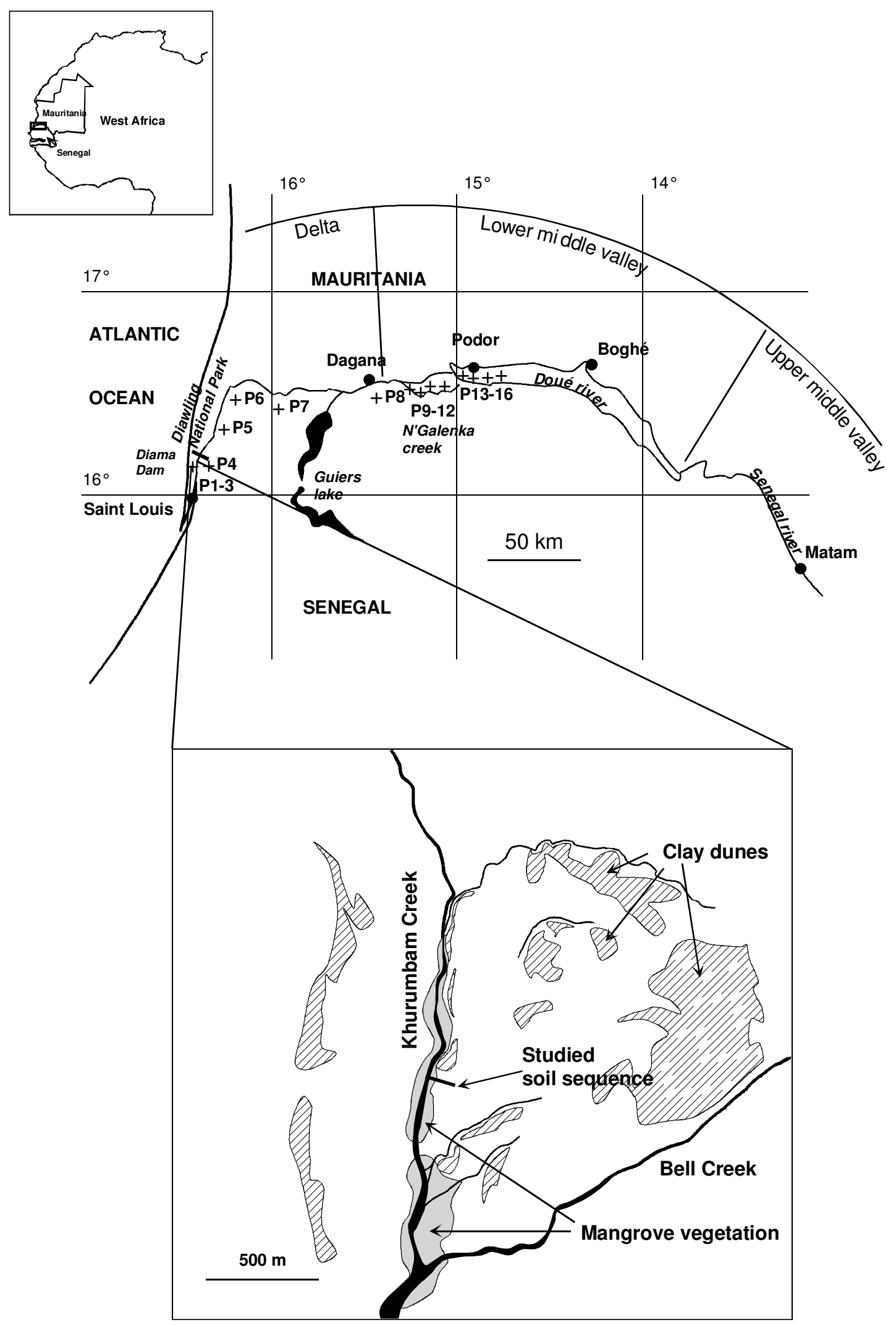




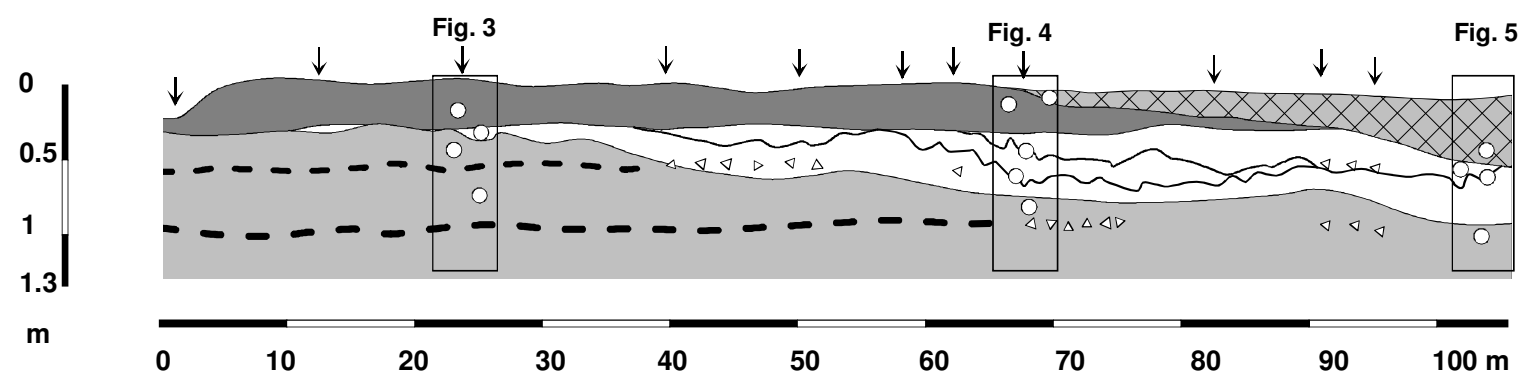

West

East

Mud with pyrite and jarosite ( $\mathrm{Gr}$ and $\mathrm{Bj}$ horizon)

Superficial silty horizon (Bjo and A horizon)

Sandy horizon

Main clay strips
Vertic clay horizon

$\diamond \triangleright$ Gypseous nodules

- Shells and shell fragments

Sampling points

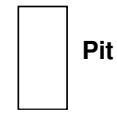

$\downarrow$ Bore hole
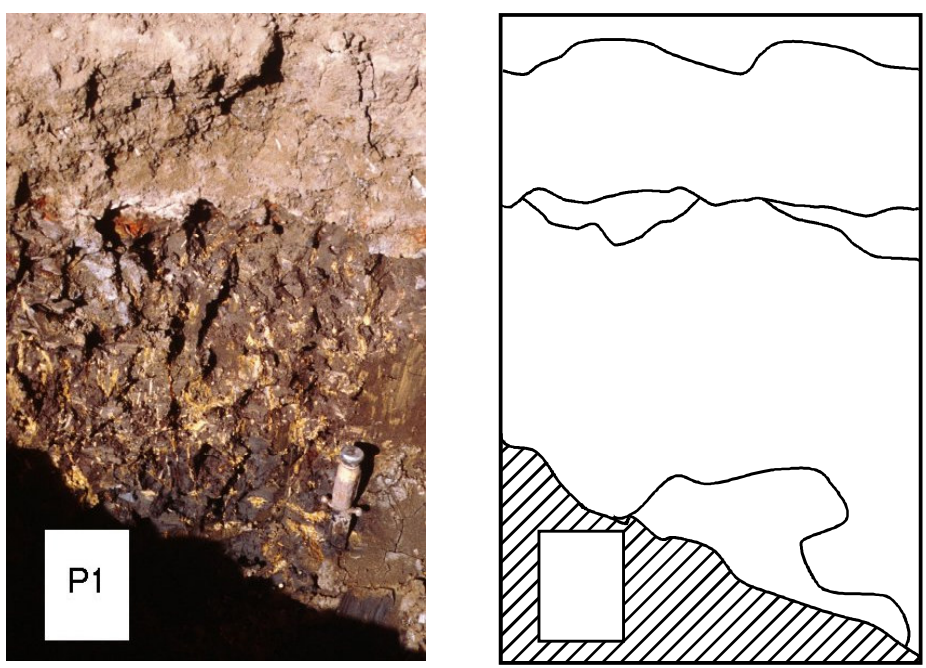

Soil surface

$20 \mathrm{~cm}$

Superficial silty horizon

Discontinuous bleached sandy horizon with reddish hematite mottles

Grey-brown, half ripe and severely acidic silty-clay material

with yellow mottles of jarosite

Unripe silty clay material with pyrite 

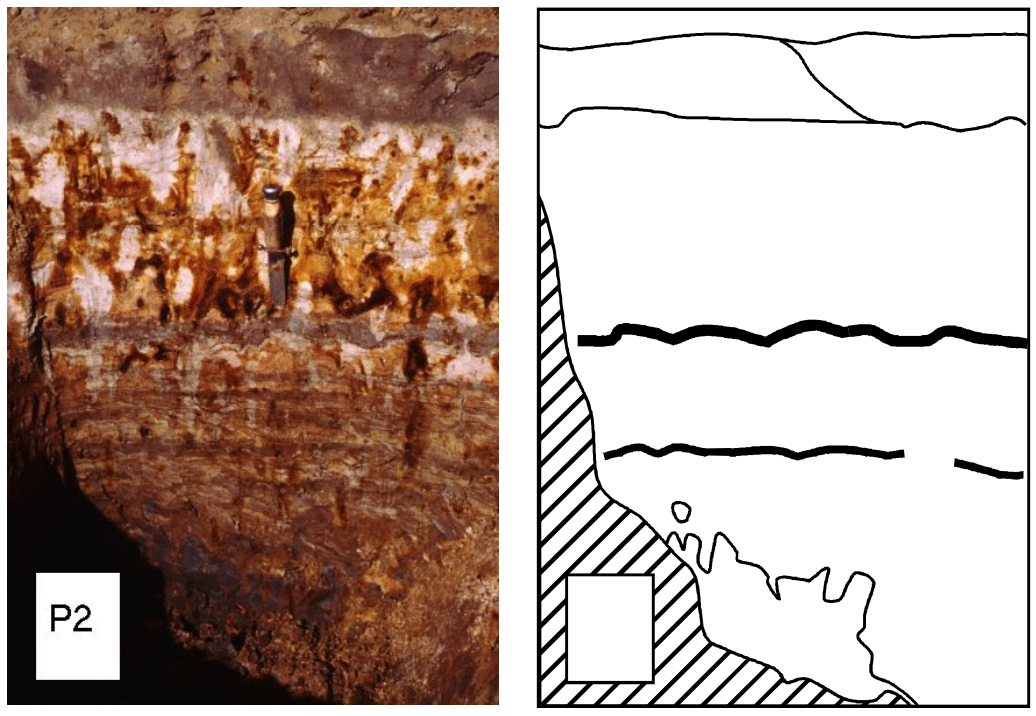

Soil surface

$20 \mathrm{~cm}$

Superficial silty $\backslash$ clay horizon

Bleached sandy horizon coloured by iron oxide

Main clay laminae

Unripe silty clay material with pyrite
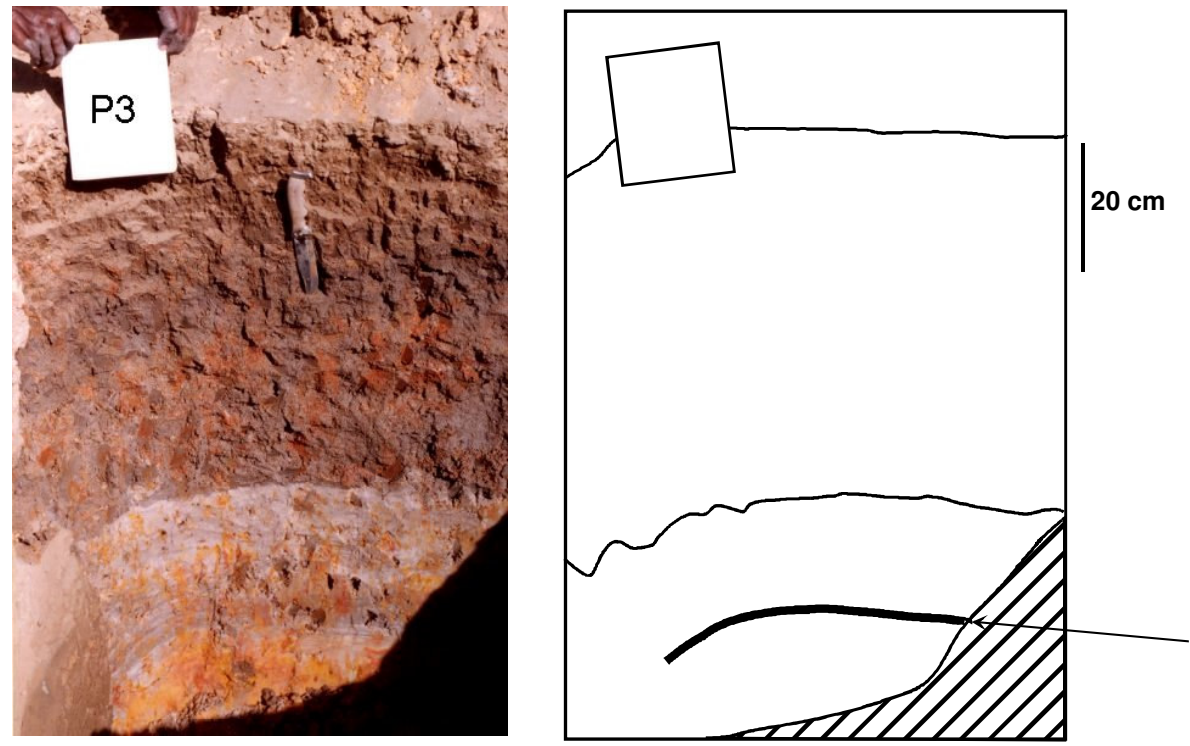

Soil surface

Superficial clay horizon with vertic structure

Bleached sandy horizon coloured by iron oxide

main clay laminae 
Delta

Middle valley

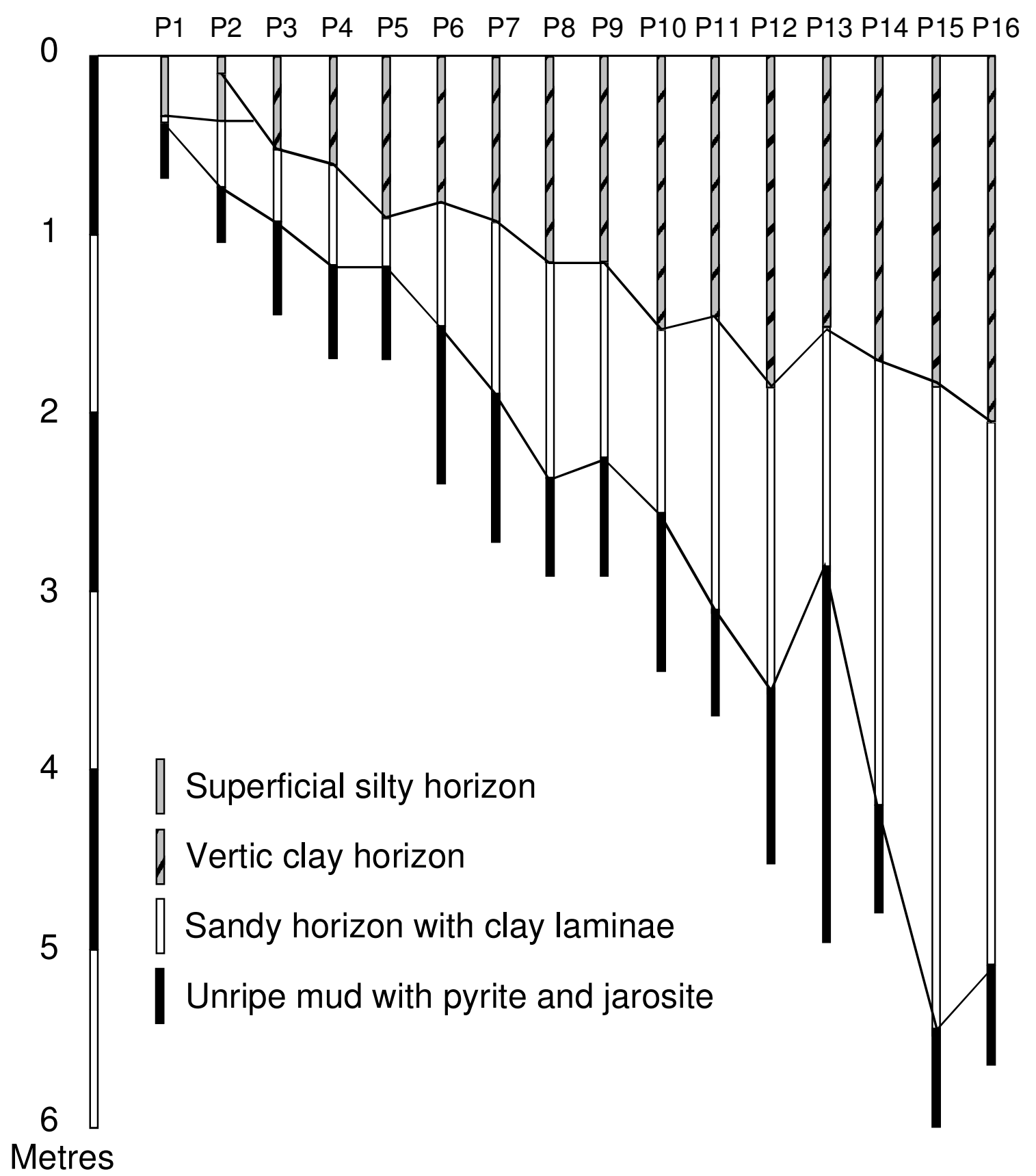




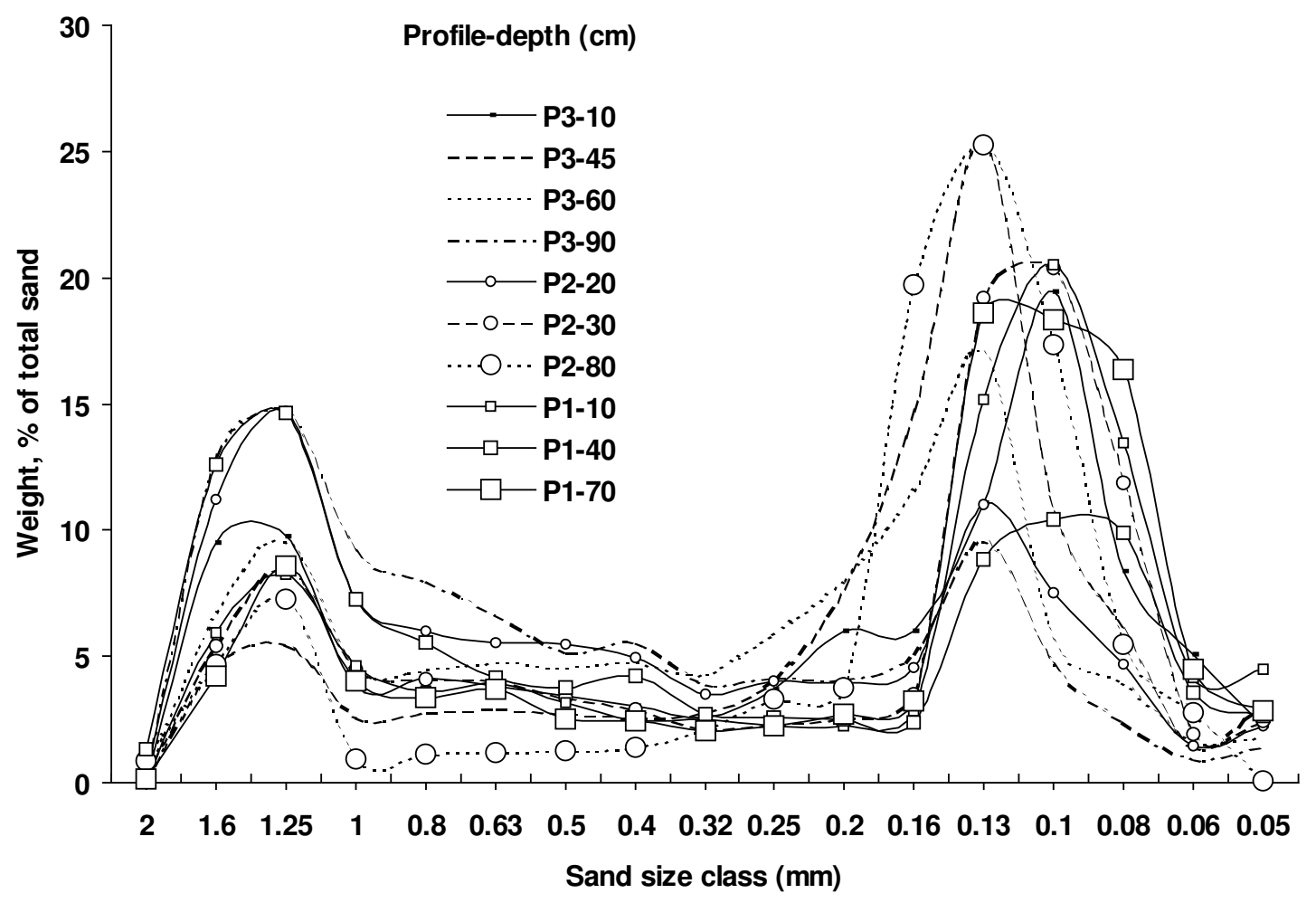

